\title{
Immobilization of Camel Liver Catalase on Nanosilver-Coated Cotton Fabric
}

\author{
Omar A. M. Al-Bar ${ }^{1}$, Reda M. El-Shishtawy ${ }^{2,3, * \mathbb{C}}$ and Saleh A. Mohamed ${ }^{4} \mathbb{C}$ \\ 1 Biochemistry Department, Faculty of Science, King Abdulaziz University, Jeddah 21589, Saudi Arabia; \\ oalbar@kau.edu.sa \\ 2 Chemistry Department, Faculty of Science, University of Jeddah, Jeddah 21589, Saudi Arabia \\ 3 Dyeing, Printing and Textile Auxiliaries Department, Textile Research Division, National Research Centre, \\ Dokki, Cairo 12622, Egypt \\ 4 Molecular Biology Department, National Research Centre, Dokki, Cairo 12622, Egypt; saleh38@hotmail.com \\ * Correspondence: relshishtawy@kau.edu.sa
}

Citation: Al-Bar, O.A.M.;

El-Shishtawy, R.M.; Mohamed, S.A. Immobilization of Camel Liver Catalase on Nanosilver-Coated Cotton Fabric. Catalysts 2021, 11, 900. https://doi.org/10.3390/

catal11080900

Academic Editors: Aniello Costantini and Valeria Califano

Received: 10 July 2021

Accepted: 25 July 2021

Published: 26 July 2021

Publisher's Note: MDPI stays neutral with regard to jurisdictional claims in published maps and institutional affiliations.

Copyright: (c) 2021 by the authors. Licensee MDPI, Basel, Switzerland. This article is an open access article distributed under the terms and conditions of the Creative Commons Attribution (CC BY) license (https:// creativecommons.org/licenses/by/ $4.0 /)$.

\begin{abstract}
Nanoparticles have the advantage of a superior surface area to volume ratio, and thus such materials are useful for enzyme immobilization. A silver nanoparticle coated cotton fabric (AgNp-CF) is used to immobilize camel liver catalase in the present work. The effect of loading levels of AgNp inside cotton fabrics on the immobilization of catalase was investigated. The results revealed that a $6 \mathrm{~mL}$ loading level of $\mathrm{AgNp}$ precursor (silver nitrate, $2 \mathrm{mM}$ ) at $\mathrm{pH} 8$ showed the maximum immobilization efficiency (76\%). The morphological properties of the cotton fabric (CF), AgNp-CF and AgNp-CF-catalase were characterized by SEM. The reusability of the immobilized enzyme was tested over ten reuses to show a $67 \%$ retained function of its initial activity. Compared with the soluble enzyme's working $\mathrm{pH}$ (6.5), a rather broader working $\mathrm{pH}$ (6.5-7.0) was observed for the immobilized catalase. Additionally, the optimum working temperature increased from 30 for the soluble enzyme to $40{ }^{\circ} \mathrm{C}$ for the immobilized one, indicating thermal stability. The free and immobilized catalase enzyme's Km values were 22.5 and $25 \mathrm{mM} \mathrm{H}_{2} \mathrm{O}_{2}$, respectively, reflecting the enzyme's effective properties. The inhibitory effect of metal ions on the enzyme activity was higher toward soluble catalase than the immobilized catalase. This work has developed a method for immobilizing catalase to be useful for several applications.
\end{abstract}

Keywords: catalase; nanosilver; cotton; immobilization

\section{Introduction}

Catalase is an enzyme that catalyzes the decomposition of $\mathrm{H}_{2} \mathrm{O}_{2}$ [1-3]. Catalase is widely produced by various microbes, plants, and animals, and as such, it protects the living cells from the toxicity of $\mathrm{H}_{2} \mathrm{O}_{2}$ [4]. Catalase has found different applications in food science, food production and medical fields [5-7]. It is also used to decompose residual $\mathrm{H}_{2} \mathrm{O}_{2}$ after the bleaching process of textile fabrics [8,9]. The large scale and/or industrial application of enzymes necessitate their immobilization onto a solid support. The immobilized enzyme has several advantages over the free one, such as easier recovery and purification, enhanced stability, protection and reduced contamination [10]. Enzymes as fragile proteins have been immobilized by several techniques including, adsorption [11,12], covalent binding [13], entrapment [14], encapsulation [15,16], and electrochemical polymerization [17,18]. Many supports have been used such as chitosan [19,20], nanodiamond [21], polyethylene terephthalate [22], polyketone [23], wool [24], $\mathrm{PPyAgNp} / \mathrm{Fe}_{3} \mathrm{O}_{4}$-nanocomposite [25] and starch [26]. Specifically, catalase immobilization onto different solid supports such as chitosan, collagen, fibers, inorganic oxides [27-29] and others, have been pursued [30-32].

A recent report on catalase immobilization on silk fibroins has been published [33]. The solid support for enzyme immobilization should fulfil some essential characteristics such as water insolubility with a sufficient surface area and less negative impact on the 
enzyme activity [34]. These characteristics are nicely met with AgNp-CF as solid support.It was hypothesized that the in situ formed $\mathrm{AgNp}$ inside cotton fabrics would furnish a suitable solid support for the successful immobilization of catalase enzyme via Ag-catalase bindings. Therefore, camel liver catalase was immobilized on AgNp-CF in this study.

\section{Results and Discussion}

It was envisioned that silver-nano-coated cotton fabric made by in situ reduction of silver nitrate $[35,36]$ would furnish a good solid support amenable for enzyme immobilization by virtue of its content of AgNp. Accordingly, different loading levels of AgNp were in situ formed using different volumes $(\mathrm{mL})$ of the precursor (silver nitrate, $2.5 \mathrm{mM}$ ). Different pHs $(5,7,8)$ were also studied for the immobilization of catalase. The results (Table 1) revealed that a $6 \mathrm{~mL}$ loading level of $\mathrm{AgNp}$ at $\mathrm{pH} 8$ showed the maximum immobilization efficiency (76\%). The lowest efficiency of immobilization of catalase was observed at 1 and $9 \mathrm{~mL}$ loading levels of AgNp and at pH 5. Such a result of low immobilization efficiency at a high loading level of AgNp could be refer to the increased binding sites of the enzyme with $\mathrm{AgNp}-\mathrm{CF}$, which led to a change in the enzyme stereochemical configuration. At a low concentration of $\mathrm{AgNp}$, the rate of immobilization of catalase is attributed to the low content of AgNp, which binds to the enzyme. On the other hand, the concentration effect of enzyme on its rate of immobilization was studied at the optimum conditions ( $\mathrm{pH} 8.0$ with $6 \mathrm{~mL}$ AgNp precursor) of the immobilization process. Figure 1 shows that the enzyme activity increased with increasing its concentration till 20 units/g AgNp-CF (60\% relative activity), which remained stable up to 25 units/g AgNp-CF. The low residual activity percentage at a lower enzyme concentration could be due to the concentration effect.

Table 1. Effect of different AgNp loading level (volume from silver nitrate precursor, $2.5 \mathrm{mM}$ ) per $0.3 \mathrm{~g}$ cotton fabric and different $\mathrm{pH}$ 's on the immobilization efficiency of catalase.

\begin{tabular}{cccc}
\hline \multirow{2}{*}{ AgNp Loading Level (mL) } & \multicolumn{3}{c}{ Immobilization Efficiency\% } \\
\cline { 2 - 4 } & $\mathbf{p H ~ 5 . 0}$ & $\mathbf{p H ~ 7 . 0}$ & $\mathbf{p H ~ 8 . 0}$ \\
\hline 0 & $4 \pm 0.12$ & $4.6 \pm 0.13$ & $5.1 \pm 0.11$ \\
1 & $8.6 \pm 0.23$ & $9.1 \pm 0.3$ & $10.5 \pm 0.33$ \\
3 & $14.3 \pm 0.32$ & $15.5 \pm 0.34$ & $20 \pm 0.48$ \\
6 & $53 \pm 1.60$ & $62 \pm 1.80$ & $76 \pm 2.20$ \\
9 & $27 \pm 0.42$ & $28.7 \pm 0.65$ & $31 \pm 0.81$ \\
\hline
\end{tabular}

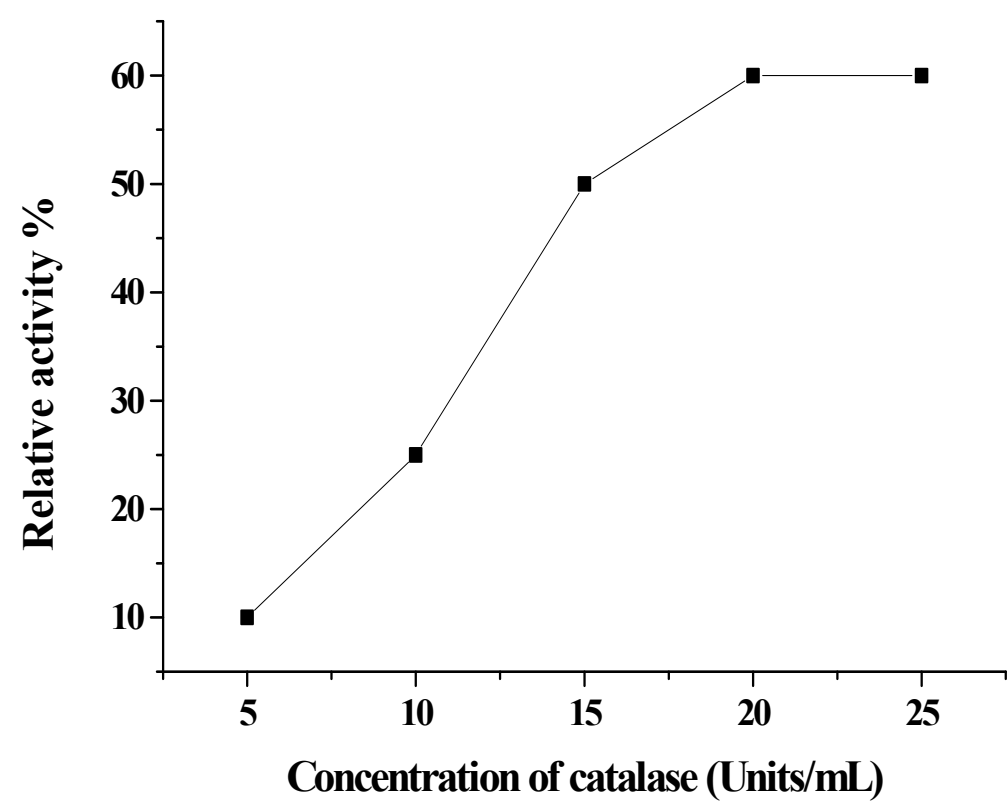

Figure 1. The influence of enzyme concentration on the rate of immobilized catalase. 
The morphology of the CF, AgNp-CF and AgNP-CF-catalase samples are shown in Figure 2. As evidence of the loading success of AgNp onto cotton fabric and its enzyme immobilized form, the morphological changes were assessed using SEM. Figure 2 shows the morphological changes for samples A (blank), B (6 mL sample AgNp coated fabric), and C (catalase immobilized onto $6 \mathrm{~mL}$ sample AgNp coated fabric). It is clearly observed that sample A appeared as a smooth surface and became dotted with AgNp after being coated with a $6 \mathrm{~mL}$ loading level. Upon enzyme immobilization, the dots became covered with the enzyme that appeared as small aggregates.

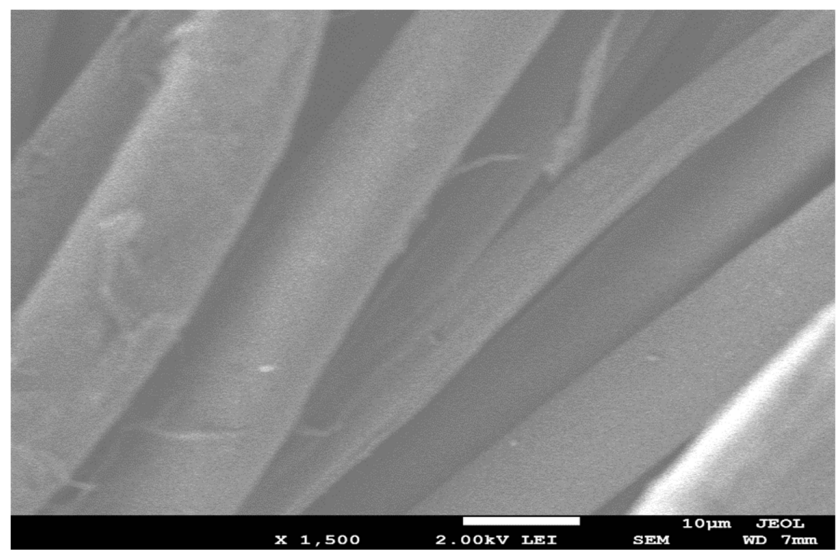

(A)

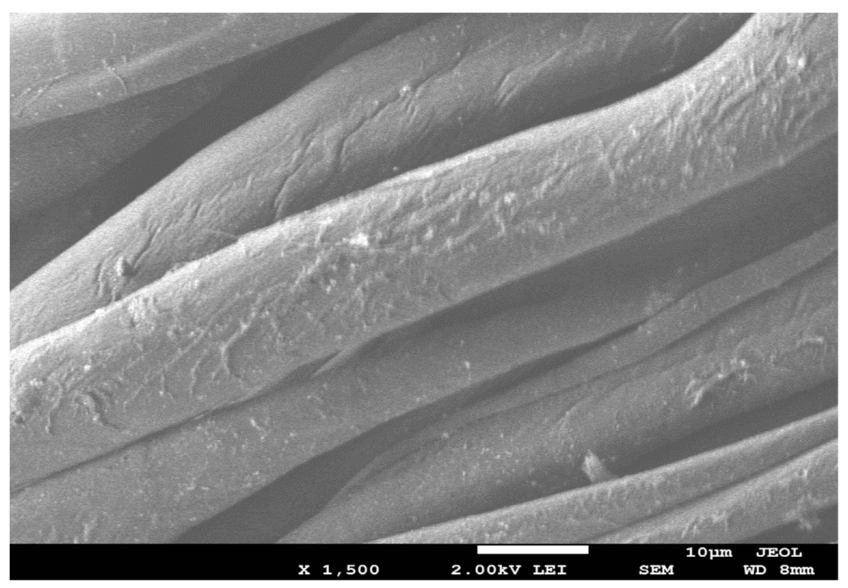

(B)

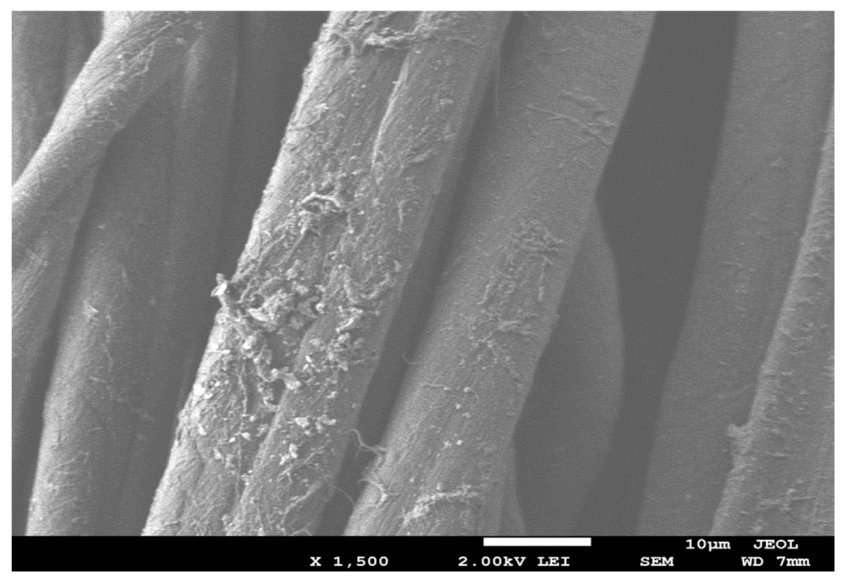

(C)

Figure 2. SEM images of $\mathrm{CF}(\mathrm{A}), 6 \mathrm{~mL}$ sample $\mathrm{AgNp}-\mathrm{CF}(\mathbf{B})$, catalase immobilized onto B sample (C). 
The advantage of enzyme immobilization in terms of its reusability was assessed. The support was thoroughly washed with water after each reuse. In Figure 3, over ten reuses and the results indicated a $67 \%$ retention of its initial activity. Similar results of reusability of immobilized catalases were determine $[37,38]$. The reduction of the activity after each reuse is due to the assay conditions $[39,40]$.

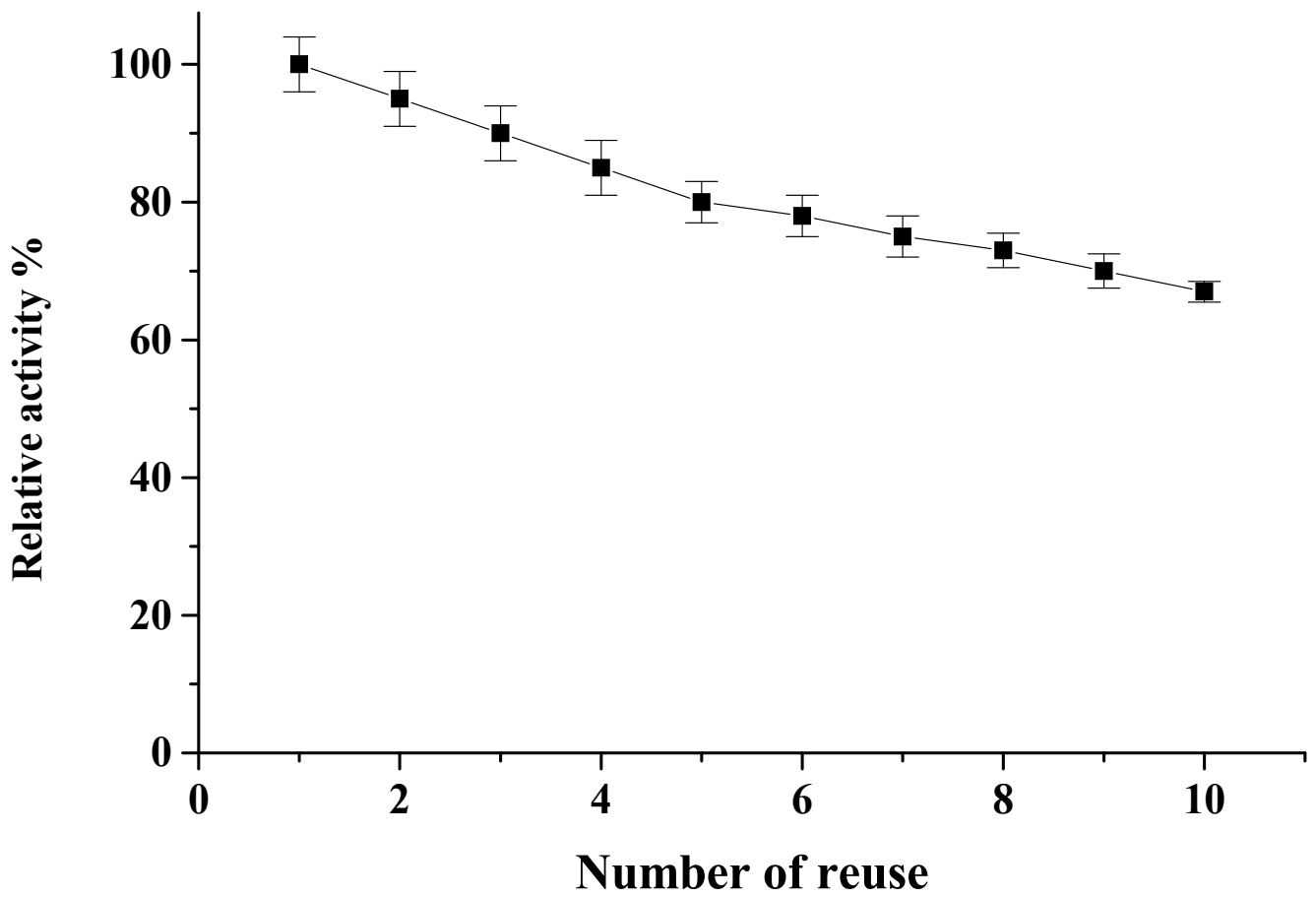

Figure 3. Reuse of immobilized catalase in assay.

The solid supports for enzyme immobilization could have a large multi-crosslinkings, which maintained the structure of enzyme from any change of $\mathrm{pH}$ and temperature $[41,42]$. This immobilization effect can also be manifested by studying the influne of $\mathrm{pH}$ on its activity compared with its free form. Thus, the assessment was made $\mathrm{pH}^{\prime} \mathrm{s} 4.0-8.5$ (Figure 4 ). The $\mathrm{pH}$ was changed from 6.5 for free form to broad $\mathrm{pH}$ at 6.5-7.0 for immobilized form. The free catalase and immobilized on bentonite-cysteine (Bent-Cys) microcomposite had optimum $\mathrm{pH}$ at 7.0 [43] and increased to $\mathrm{pH} 7.5$ using chitosan/ $\mathrm{ZnO} / \mathrm{Fe}_{2} \mathrm{O}_{3}$ nanocomposite [27].

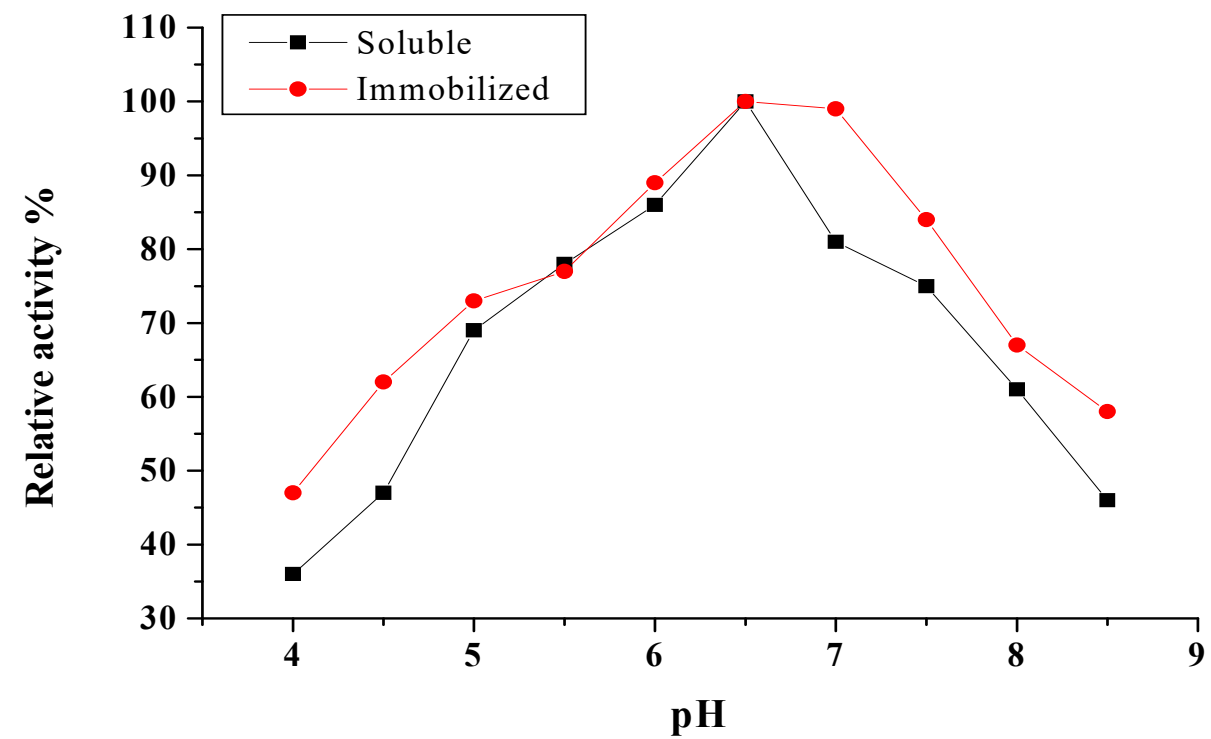

Figure 4. The influence of $\mathrm{pH}$ on catalase activity. 
The influence of temperature on catalase activity is appeared in Figure 5. The optimum working temperature increased from 30 for free enzyme to $40^{\circ} \mathrm{C}$ for the immobilized one. The immobilized catalase on terpolymer (acrylonitrile, acrylic acid, and vinyl porphyrin) was $35^{\circ} \mathrm{C}$, and $25^{\circ} \mathrm{C}$ for free catalase $[43,44]$. The thermal stability study was shown in Figure 6. The soluble form and the immobilized form were steady up to 30 and $40{ }^{\circ} \mathrm{C}$, respectively. In contrast, the same thermal stability of the free catalase or reduced graphene oxide $-\mathrm{Fe}_{3} \mathrm{O}_{4} /$ catalase was detected [45]. The high thermal stability of the immobilized enzyme referred to multipoints of enzyme on the bear [46]. The thermal steady of the enzymes is required for industrial applications [47].

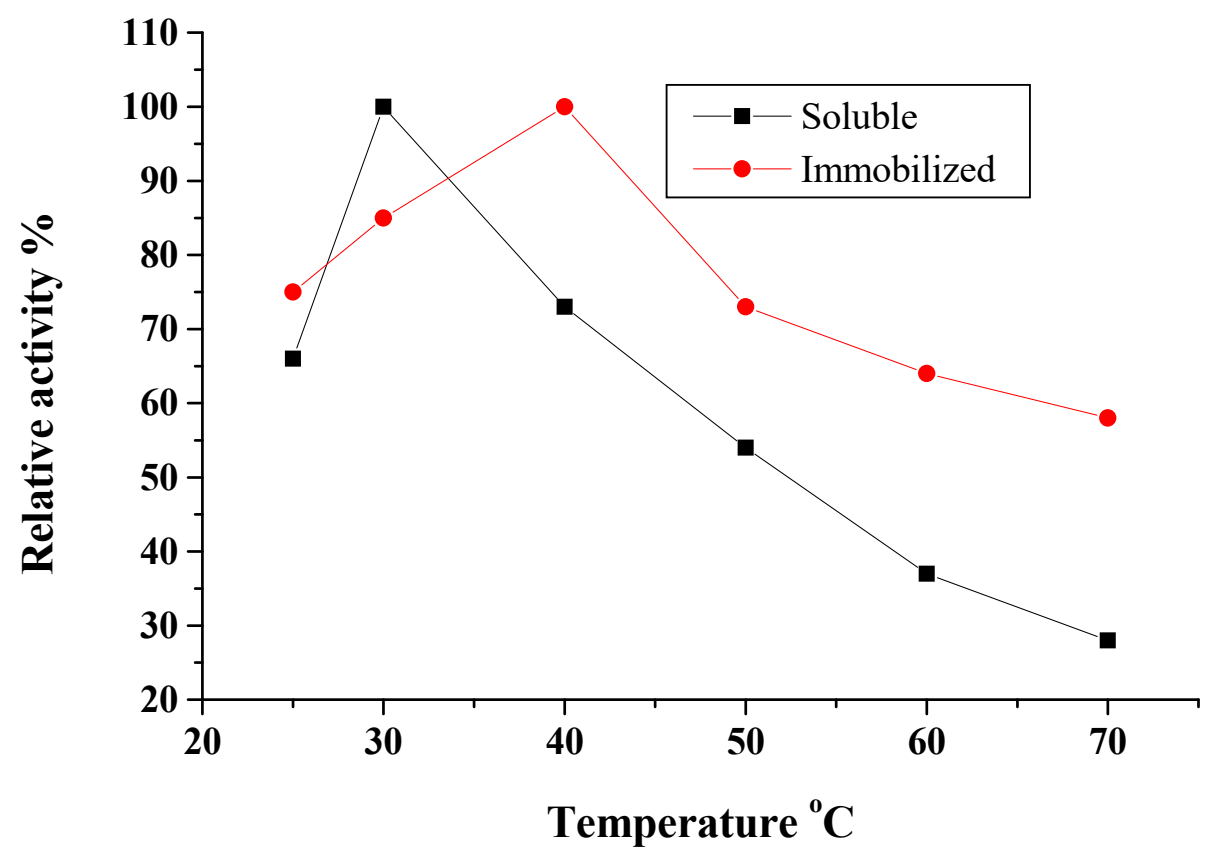

Figure 5. Optimum temperature of soluble catalase and immobilized catalase. Each point represents the average of two experiments.

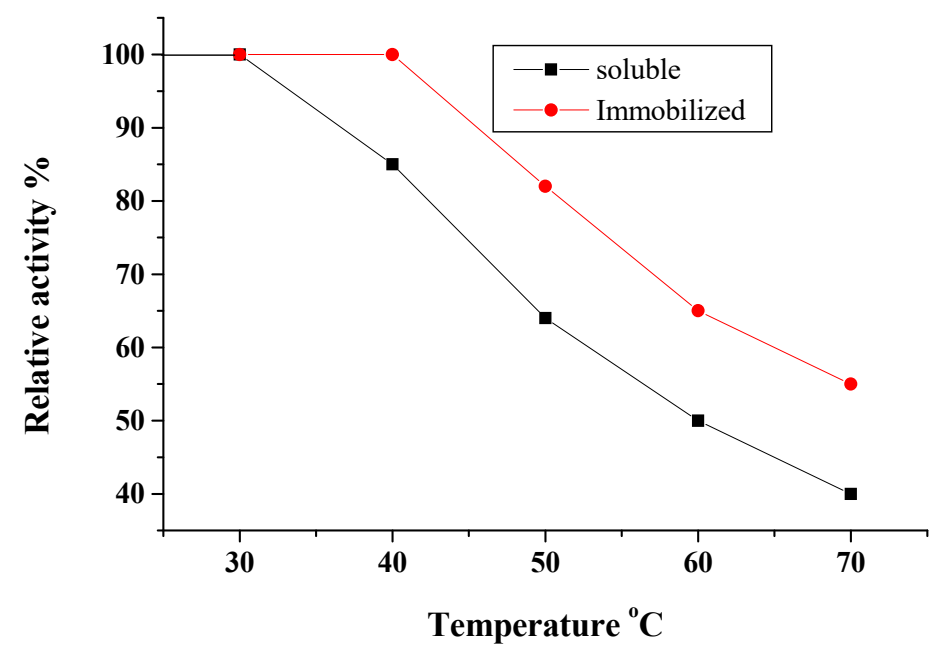

Figure 6. Thermal stability of soluble catalase and immobilized catalase.

The free and immobilized catalase enzymes' Km values (Figure 7) were 22.5 and $25 \mathrm{mM} \mathrm{H}_{2} \mathrm{O}_{2}$, respectively, reflecting the enzymes' effective properties. The values of Vmax of soluble catalase and immobilized catalase were 1.4 and 0.69 units $/ \mathrm{mL}$, respectively. Furthermore, the ratio Vmax/Km of the soluble catalase and the immobilized one were 0.062 and 0.027 , respectively, where free catalase had more affinity toward substrate. This 
affinity difference is a kind of regulation for the immobilized enzyme activity due to the uneasy accessibility of its active sites by the substrate. In other words, immobilization of the enzyme could impose some structural orientation, which lowers its affinity toward the substrate. A similar study was reported by Alptekin et al. [48]. On the other hand, the $\mathrm{Km}$ of the catalase was significantly smaller upon immobilization on magnetic polymeric nanospheres [49].

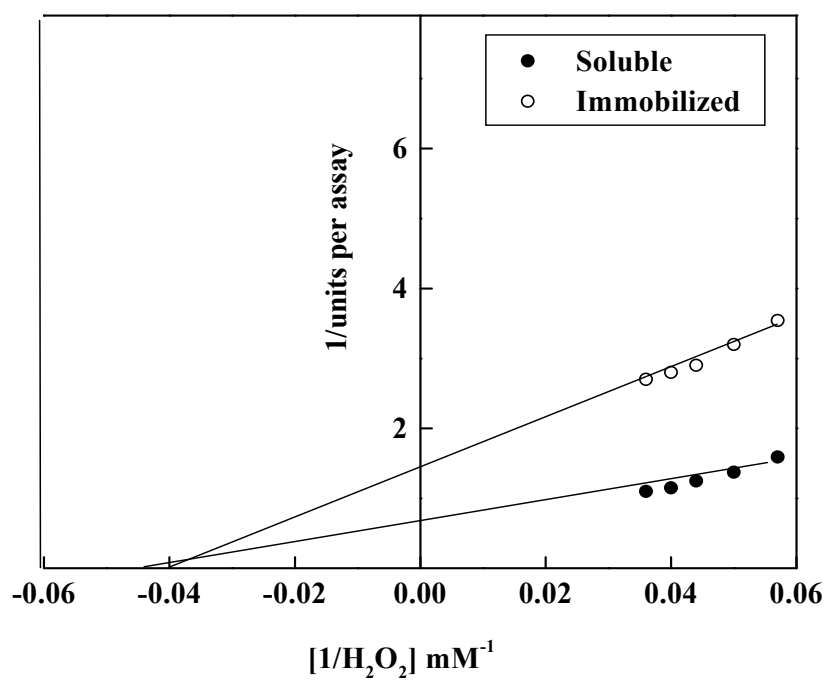

Figure 7. Lineweaver-Burk plot relating soluble catalase and immobilized catalase reaction velocity to $\mathrm{H}_{2} \mathrm{O}_{2}$ concentrations.

The inhibitory effect of metal cations on the enzyme activity is shown in Table 2. Generally, the inhibitory effect was higher toward soluble catalase than the immobilized one. For example, $\mathrm{Cu}^{2+}$ enhanced the activity of the immobilized catalase without affecting the soluble one. $\mathrm{Co}^{2+}$, however, decreased the activity of soluble catalase without affecting the immobilized one. The other metal ions tested $\left(\mathrm{Cd}^{2+}, \mathrm{Ni}^{2+}, \mathrm{Zn}^{2+}\right.$ and $\left.\mathrm{Hg}^{2+}\right)$ had a more inhibitory effect toward the soluble catalase compared to the immobilized catalase. In the contrast, $\mathrm{Cu}$ caused an inhibitory effect on the catalase immobilized onto chitosan [37].

Table 2. The effect of $5 \mathrm{mM}$ metal cations on the soluble and the immobilized catalase.

\begin{tabular}{ccc}
\hline \multirow{2}{*}{ Metal } & \multicolumn{2}{c}{ Relative Activity\% } \\
\cline { 2 - 3 } & Soluble Catalase & Immobilized Catalase \\
\hline Control & 100 & 100 \\
$\mathrm{Cu}^{2+}$ & 95 & 130 \\
$\mathrm{Co}^{2+}$ & 79 & 95 \\
$\mathrm{Cd}^{2+}$ & 65 & 85 \\
$\mathrm{Ni}^{2+}$ & 45 & 62 \\
$\mathrm{Zn}^{2+}$ & 27 & 46 \\
$\mathrm{Hg}^{2+}$ & 15 & 32 \\
\hline
\end{tabular}

\section{Materials and Methods}

\subsection{Camel Liver Catalase}

Camel liver catalase was previously purified and characterized [50].

\subsection{Catalase Assay}

The activity of catalase was detected based on procedure of Bergmeyer [51]. The one $\mathrm{ml}$ assay includes $25 \mathrm{mM} \mathrm{H}_{2} \mathrm{O}_{2}$ and suitable amount enzyme, which adjusted at $\mathrm{pH} 7$ by used $75 \mathrm{mM}$ sodium phosphate buffer. The decrease in absorbance 0.1 at $240 \mathrm{~nm}$ during $1 \mathrm{~min}$ is considered one unit. 


\subsection{Preparation of Silver Nanoparticles-Cotton Fabric}

Mill-scoured and bleached cotton fabric $\left(130 \mathrm{~g} / \mathrm{m}^{2}\right)$ was obtained from Misr El-Mehala Co. (El-Mehala, Egypt). The in situ formed AgNp were made following our previously reported method [35,36]. Typically, four loading levels of silver nanoparticles on the cotton fabric were made using four volumes $(1,3,6,9 \mathrm{~mL})$ of silver nitrate $2.5 \mathrm{mM}$ per $0.3 \mathrm{~g}$ fabric. Four equal pieces of wetted cotton fabric $(0.3 \mathrm{~g})$ were introduced in a loading bath containing a certain amount of silver nitrate, as mentioned above. Then cetyltrimethylammonium bromide (CTAB) $(1 \mathrm{~mL}, 0.5 \mathrm{mM})$ and glucose $(5 \mathrm{~mL}, 2.5 \mathrm{mM})$ were added, and the mixture was shaken, then sodium hydroxide $(5 \mathrm{~mL}, 25 \mathrm{mM})$ and a certain amount of water were added to complete $20 \mathrm{~mL}$ of the batch, and the mixture was shaken for a further $20 \mathrm{~min}$ at $50^{\circ} \mathrm{C}$. The loading bath was drained, and the coated samples were thoroughly rinsed with water and air-dried.

\subsection{Procedure of Immobilization}

The immobilization procedure was done by immersion of camel liver catalase with $\mathrm{AgNp}-\mathrm{CF}$ at different $\mathrm{pH}$ 's for $12 \mathrm{~h}$. The liquid solution was decanted and the support was dried at room temperature. The immobilization efficiency $\%$ was detected from this formula:

$$
\begin{aligned}
\text { Immobilization efficiency } \%= & \text { units of immobilized enzyme } / \text { units of initial } \\
& \text { enzyme } \times 100
\end{aligned}
$$

\subsection{Morphology Characterization}

The SEM of AgNp-CF-catalase was investigated by electron microscope (Quanta FEG 450, FEI, Amsterdam, The Netherland).

\subsection{The Reuse of AgNp-CF-Catalase}

The reusability of $\mathrm{AgNp}-\mathrm{CF}-$ catalase was evaulated by reuse the assay several times. The first detection of catalase was considered as $100 \%$. The activity of each reuse was considered as remaining catalase.

\subsection{Enzyme Characterization}

The Kinetic studies of enzyme including $\mathrm{Km}$ and Vmax were detected using LineweaverBurk plot. The effect of temperature $\left(30-80{ }^{\circ} \mathrm{C}\right)$ and $\mathrm{pH}(4-9)$ on enzyme activity was determined.

\subsection{Effect of Metal Ions}

The effect of metal cations on enzyme activity was determined by incubation of enzyme with metal cations for $15 \mathrm{~min}$ before adding $\mathrm{H}_{2} \mathrm{O}_{2}$. The assay without metal cations was considered $100 \%$ activity.

\section{Conclusions}

In this study the presence of AgNp inside cotton fabrics would facilitate the immobilization of a catalase enzyme via Ag-catalase bindings. The results showed that the immobilized catalase by AgNp-cotton fabric improved its resistance toward $\mathrm{pH}$, heat and metal ions. Therefore, the immobilized catalase could be used for several applications.

Author Contributions: O.A.M.A.-B., R.M.E.-S. and S.A.M. contributed to the ideas, executed all the experiments, analyzed and interpreted the data, as well as wrote, reviewed, and edited the manuscript. All authors have read and agreed to the published version of the manuscript.

Funding: This work was supported by the Deanship of Scientific Research (DSR), King Abdulaziz University.

Data Availability Statement: Data are provided in the manuscript. 
Acknowledgments: This project was funded by the Deanship of Scientific Research (DSR) at King Abdulaziz University, Jeddah, under grant No. (1437-130-663). The authors, therefore, acknowledge with thanks, DSR for their technical and financial support.

Conflicts of Interest: The authors declare no conflict of interest.

\section{References}

1. Hernandez, K.; Berenguer-Murcia, A.; Rodrigues, R.C.; Fernandez, L.R. Hydrogen peroxide in biocatalysis. A dangerous liaison. Curr. Org. Chem. 2012, 16, 2652-2672. [CrossRef]

2. Shamsipur, M.; Asgari, M.; Maragheh, M.; Moosavi-Movahedi, A. A novel impedimetric nanobiosensor for low level determination of hydrogen peroxide based on biocatalysis of catalase. Bioelectrochemistry 2012, 83, 31-37. [CrossRef] [PubMed]

3. Plumere, N.; Henig, J.; Campbell, W.H. $\mathrm{O}_{2}$ removal system for electrochemical analysis under ambient air: Application in an amperometric nitrate biosensor. Anal. Chem. 2012, 84, 2141-2146. [CrossRef] [PubMed]

4. Chelikani, P.; Fita, I.; Loewen, P.C. Diversity of structures and properties among catalases. Cell Mol. Life Sci. 2004, 61, 192-208. [CrossRef]

5. Akertek, E.; Tarhan, L. Characterization of Immobilized Catalases and Their Application in Pasteurization of $\mathrm{Milk}_{\mathrm{k}}$ with $\mathrm{H}_{2} \mathrm{O}_{2}$. Appl. Biochem. Biotechnol. 1995, 50, 291-303. [CrossRef]

6. Abdel-Mageed, H.M.; El-Laithy, H.M.; Mahran, L.G.; Fahmy, A.S.; Mader, K.; Mohamed, S.A. Development of novel flexible sugar ester vesicles as carrier systems for the antioxidant enzyme catalase for wound healing applications. Proc. Biochem 2012, 47, 1155-1162. [CrossRef]

7. Abdel-Mageed, H.M.; Fahmy, A.S.; Shaker, D.S.; Mohamed, S.A. Development of novel delivery system for nanoencapsulation of catalase: Formulation, characterization, and in vivo evaluation using oxidative skin injury model. Artif. Cells Nanomed. Biotechnol. 2018, 46 (Suppl. S1), S362-S371. [CrossRef] [PubMed]

8. Tzaov, T.; Costa, S.; Guebitz, G.M.; Cavaco-Paulo, A. Dyeing in catalase-treated bleaching baths. Color. Technol. 2001, 117, 1-5. [CrossRef]

9. Soares, J.C.; Moreira, P.R.; Queiroga, A.C.; Morgado, J.; Malcata, F.X.; Pintado, M.E. Application of immobilized enzyme technologies for the textile industry: A review. Biocatal. Biotrans. 2011, 29, 223-237. [CrossRef]

10. Kulshrestha, Y.; Husain, Q. Bioaffinity-based an inexpensive and high yield procedure for the immobilization of turnip (Brassica rapa) peroxidase. Biomol. Eng. 2006, 23, 291-297. [CrossRef] [PubMed]

11. Zhang, J.Z.; Li, B.; Wang, Z.X.; Cheng, G.J.; Dong, S.J. Functionalized inorganic-organic composite material derivated by sol-gel for construction of mediated amperometric hydrogen peroxide biosensor. Anal. Chim. Acta 1999, 388, 71-78. [CrossRef]

12. Chen, W.B.; Pardue, H.L. Pseudo-equilibrium approach to the design and use of enzyme-based amperometric biosensors evaluated using a sensor for hydrogen peroxide. Anal. Chim. Acta 2000, 409, 123-130. [CrossRef]

13. Yabuki, S.; Mizutani, F.; Hirata, Y. Hydrogen peroxide determination based on a glassy carbon electrode covered with polyion complex membrane containing peroxidase and mediator. Sens. Actuators B 2000, 65, 49-51. [CrossRef]

14. Liu, B.H.; Yan, F.; Kong, J.L.; Deng, J.Q. A reagentless amperometric biosensor based on the coimmobilization of horseradish peroxidase and methylene green in a modified zeolite matrix. Anal. Chim. Acta 1999, 386, 31-39. [CrossRef]

15. Abdulaal, W.H.; Almulaiky, Y.Q.; El-Shishtawy, R.M. Encapsulation of HRP enzyme onto a magnetic Fe3O4 Np-PMMA film via casting with sustainable biocatalytic activity. Catalysts 2020, 10, 181. [CrossRef]

16. Aldhahri, M.; Almulaiky, Y.Q.; El-Shishtawy, R.M.; Al-Shawafi, W.M.; Salah, N.; Alshahrie, A.; Alzahrani, H.A. Ultra-thin 2D $\mathrm{CuO}$ nanosheet for HRP immobilization supported by encapsulation in a polymer matrix: Characterization and dye degradation. Catal. Lett. 2021, 151, 232-246. [CrossRef]

17. Sergereva, T.A.; Lavrik, N.V.; Rachkov, A.E.; Kazantseva, Z.I.; Piletsky, S.A.; El'skaya, A.V. Hydrogen peroxide-sensitive enzyme sensor based on phthalocyanine thin film. Anal. Chim. Acta 1999, 391, 289-297. [CrossRef]

18. Fortier, G.; Brassard, E.; Belanger, D. Optimization of a polypyrrole glucose-oxidase biosensor. Biosens. Bioelectron. 1990, 5, 473-490. [CrossRef]

19. Mohamed, S.A.; Aly, A.S.; Mohamed, T.M.; Salah, H.A. Immobilization of horseradish peroxidase on non-woven polyester fabric coated with chitosan. Appl. Biochem. Biotechnol. 2008, 144, 169-179. [CrossRef]

20. Mohamed, S.A.; Al-Malki, A.L.; Kumosani, T.A.; El-Shishtawy, R.M. Horseradish peroxidase and chitosan: Activation, immobilization and comparative results. Int. J. Biol. Macromol. 2013, 60, 295-300. [CrossRef] [PubMed]

21. Alshawafi, W.M.; Aldhahri, M.; Almulaiky, Y.Q.; Salah, N.; Moselhy, S.S.; Ibrahim, I.H.; El-Shishtawy, R.M.; Mohamed, S.A. Immobilization of horseradish peroxidase on PMMA nanofibers incorporated with nanodiamond. Artif. Cells Nanomed. Biotechnol. 2018, 46, S973-S981. [CrossRef]

22. Killard, A.J.; Zhang, S.; Zhao, H.; John, R.; Iwuoha, E.I.; Smyth, M.R. Development of an electrochemical flow injection immunoassay (FIIA) for the real-time monitoring of biospecific interactions. Anal. Chim. Acta 1999, 400, 109-119. [CrossRef]

23. Agostinelli, E.; Belli, F.; Tempera, G.; Murab, A.; Floris, G.; Toniolo, L.; Vavasori, A.; Fabris, S.; Momod, F.; Stevanato, R. Polyketone polymer: A new support for direct enzyme immobilization. J. Biotechnol. 2007, 127, 670-678. [CrossRef]

24. Mohamed, S.A.; Darwish, A.A.; El-Shishtawy, R.M. Immobilization of horseradish peroxidase on activated wool. Proc. Biochem. 2013, 48, 649-655. [CrossRef] 
25. Mohamed, S.A.; Al-Harbi, M.H.; Almulaiky, Y.Q.; Ibrahim, I.H.; Salah, H.A.; El-Badry, M.O.; Abdel-Aty, A.M.; Fahmy, A.S.; El-Shishtawy, R.M. Immobilization of Trichoderma harzianum $\alpha$ amylase on PPyAgNp/Fe3O4-nanocomposite: Chemical and physical properties. Artif. Cells Nanomed. Biotechnol. 2018, 46, S201-S206. [CrossRef] [PubMed]

26. El-Naggar, M.E.; Abdel-Aty, A.M.; Wassel, A.R.; Elaraby, N.M.; Mohamed, S.A. Immobilization of horseradish peroxidase on cationic microporous starch: Physico-bio-chemical characterization and removal of phenolic compounds. Int. J. Biol. Macromol. 2021, 181, 734-742. [CrossRef] [PubMed]

27. El-Shishtawy, R.M.; Ahmed, N.S.E.; Almulaiky, Y.Q. Immobilization of Catalase on Chitosan/ZnO and Chitosan/ZnO/Fe2O3 Nanocomposites: A Comparative Study. Catalysts 2021, 11, 820. [CrossRef]

28. Mohamed, S.A.; Al-Harbi, M.H.; Almulaiky, Y.Q.; Ibrahim, I.H.; El-Shishtawy, R.M. Immobilization of horseradish peroxidase on Fe3O4 magnetic nanoparticles. Electron. J. Biotechnol. 2017, 27, 84-90. [CrossRef]

29. Almulaiky, Y.Q.; Khalil, N.M.; El-Shishtawy, R.M.; Bilal, M.; Mohammed, M.M. Hydroxyapatite-decorated $\mathrm{ZrO}_{2}$ for $\alpha$-amylase immobilization: Toward the enhancement of enzyme stability and reusability. Int. J. Biol. Macromol. 2021, 167, 299-308. [CrossRef] [PubMed]

30. Cengiz, S.; Çavaş, L.; Yurdakoç, K. Bentonite and sepiolite as supporting media: Immobilizationof catalase. Appl. Clay Sci. 2012, 65-66, 114-120. [CrossRef]

31. Çetinus, S.A.; Şahin, E.; Saraydin, D. Preparation of Cu (II) adsorbed chitosan beads for catalase immobilization. Food Chem. 2009, 114, 962-969. [CrossRef]

32. Song, N.; Chen, S.; Huang, X.; Liao, X.P.; Shi, B. Immobilization of catalase by using Zr (IV)-modified collagen fiber as the supporting matrix. Proc. Biochem. 2011, 46, 2187-2193. [CrossRef]

33. Wang, P.; Qi, C.; Yu, Y.; Yuan, J.; Cui, L.; Tang, G.; Wang, Q.; Fan, X. Covalent Immobilization of Catalase onto Regenerated Silk Fibroins via Tyrosinase-Catalyzed Cross-Linking. Appl. Biochem. Biotechnol. 2015, 177, 472-485. [CrossRef] [PubMed]

34. Mubarak, N.M.; Wong, J.R.; Tan, K.W.; Sahu, J.N.; Abdullah, E.C.; Jayakumar, N.S.; Ganesan, P. Immobilization of cellulase enzyme on functionalized multiwallcarbon nanotubes. J. Mol. Catal. B Enzym. 2014, 107, 124-131. [CrossRef]

35. El-Shishtawy, R.M.; Asiri, A.M.; Al-Otaibi, M.M. Synthesis and spectroscopic studies of stable aqueous dispersion of silver nanoparticles. Spectrochim. Acta Part A Mol. Biomol. Spectrosc. 2011, 79, 1505-1510. [CrossRef]

36. El-Shishtawy, R.M.; Asiri, A.M.; Abdelwahed, N.A.M.; Al-Otaibi, M.M. In situ production of silver nanoparticle on cotton fabric and its antimicrobial evaluation. Cellulose 2011, 18, 75-82. [CrossRef]

37. Arabaci, G.; Usluoglu, A. Catalytic properties and immobilization studies ofcatalase from Malva sylvestris L. J. Chem. 2013, 2013, 686185. [CrossRef]

38. Chatterjee, U.; Kumar, A.; Sanwal, G.G. Goat liver catalase immobilized onvarious solid supports. J. Ferment. Bioeng. 1990, 70, 429-430. [CrossRef]

39. Musthapa, S.M.; Akhtar, S.; Khan, A.A.; Husain, Q. An economical simple and high yield procedure for the immobilization/stabilization of peroxidases from turnip roots. J. Sci. Ind. Res. 2004, 63, 540-547.

40. Qiu, H.J.; Xu, C.X.; Huang, X.R.; Ding, Y.; Qu, Y.B.; Gao, P.J. Immobilization of Laccase on Nanoporous Gold: Comparative Studies on the Immobilization Strategies and the Particle Size Effects. J. Phys. Chem. C 2009, 113, 2521-2525. [CrossRef]

41. Cabral, J.M.S.; Kennedy, J.F. Thermostability of Enzymes; Gupta, M.N., Ed.; Springer: Berlin/Heidelberg, Germany, 1993; pp. 163-179.

42. Kallenberg, A.I.; van Rantwijk, F.; Sheldon, R.A. Immobilization of penicillin G acylase: The key to optimum performance. Adv. Synth. Catal. 2005, 347, 905-926. [CrossRef]

43. Ozturk, N.; Tabak, A.; Akgol, S.; Denizli, A. Reversible immobilization ofcatalase by using a novel bentonite-cysteine (Bent-Cys) microcompositeaffinity sorbents. Colloids Surf. A 2008, 322, 148-154. [CrossRef]

44. Wan, L.-S.; Ke, B.-B.; Wu, J.; Xu, Z.-K. Catalase immobilization on electrospunnanofibers: Effects of porphyrin pendants and carbon nanotubes. J. Phys. Chem. C 2007, 111, 14091-14097. [CrossRef]

45. Yang, D.; Wang, X.; Shi, J.; Wang, X.; Zhang, S.; Han, P.; Jiang, Z. In situ synthesized rGO-Fe3O4 nanocomposites as enzyme immobilization support for achieving high activity recovery and easy recycling Biochem. Eng. J. 2016, 105, $273-280$.

46. Karim, Z.; Adnan, R.; Husain, Q. A $\beta$-cyclodextrin-chitosan complex as the immobilization matrix for horseradish peroxidase and its application for the removal of azo dyes from textile effluentInt. Int. Biodeterior. Biodegrad. 2012, 72, 10-17. [CrossRef]

47. Qiu, H.; Lu, L.; Huang, X.; Zhang, Z.; Qu, Y. Immobilization of horseradish peroxidase on nanoporous copper and its potential applications. Bioresour. Technol. 2010, 101, 9415-9420. [CrossRef]

48. Alptekin, O.; Tukel, S.S.; Yıldırım, D.; Dilek Alagoz, D. Immobilization of catalase onto Eupergit C and its characterization. J. Mol. Catal. B Enzym. 2010, 64, 177-183. [CrossRef]

49. Corman, N.E.; Ozturk, N.; Tuzmen, N.; Akgol, S.; Denizli, A. Magnetic polymeric nanospheres as an immobilized metal affinity chromatography (IMAC) support for catalase. Biochem. Eng. J. 2010, 49, 159-164. [CrossRef]

50. Al-Bar, O.A.M. Characterization of partially purified catalase from camel (Camelus dromedarius) liver. Afr. J. Biotechnol. 2013, 11, 9633-9640.

51. Bergmeyer, H.U. Methods of Enzymatic Analysis, 2nd ed.; Bergmeyer, H.U., Ed.; Academic Press: New York, NY, USA, 1974; Volume 1, p. 438. 